Gender, Place \& Culture

A Journal of Feminist Geography

ISSN: 0966-369X (Print) 1360-0524 (Online) Journal homepage: https://www.tandfonline.com/loi/cgpc20

\title{
An invitation to decoloniality in work on (African) men and masculinities
}

\section{Kopano Ratele}

To cite this article: Kopano Ratele (2020): An invitation to decoloniality in work on (African) men and masculinities, Gender, Place \& Culture, DOI: 10.1080/0966369X.2020.1781794

To link to this article: https://doi.org/10.1080/0966369X.2020.1781794

曲 Published online: 24 Jun 2020.

Submit your article to this journal

Q View related articles $\asymp$

View Crossmark data \lceil 


\title{
An invitation to decoloniality in work on (African) men and masculinities
}

\author{
Kopano Ratele ${ }^{a, b}$ \\ anstitute for Social and Health Sciences, University of South Africa (UNISA), Pretoria, South \\ Africa; ${ }^{b}$ Masculinity and Health Research Unit, South African Medical Research Council, Cape \\ Town, South Africa
}

\begin{abstract}
Seeing masculinity is, according to Raewyn Connell, 'a place in gender relations', what is the place accorded to males once considered property in men and masculinities studies, how are the practices of these 'former properties' fathomable as men's, and what masculinities emanate from the place these 'non-beings' occupy? This article, which emerges from being seized with thinking on coloniality, pursues the question about the possible place/s of men once regarded as property from within masculinities studies. A distinction is introduced in the way work on men and masculinities in the wake of colonialism is undertaken, the intention being to present an invitation to decoloniality.
\end{abstract}

\section{ARTICLE HISTORY}

Received 6 August 2019

Accepted 11 May 2020

\section{KEYWORDS}

Coloniality; decoloniality; masculinities; men;

(non)masculinity; (non)men

\section{Introduction}

Whereas colonialism reconfigured men's lives and masculinities, it has tended to be peripheral in the global work on men and masculinity. As Morrell (1998) observed, colonialism transformed existing masculinities and racialised gender relations, reorganizing positions of supremacy and subservience along colonial racist difference. In the wake of colonialism, which is linked to slavery, masculinity (and femininity) was given a particular colour, a specific organisation and a certain desire, among which is the patterning of relations - social, economic and sexual - between the colonized and colonizer groups, and later the former colonized and former colonizer (see Biko 1978; Fanon 1967/1952). A vexing underestimation of the constitutive force of transatlantic slavery and colonialism on masculinity, men, and their relations with each other, with women, and with other genders is however apparent in work on men and masculinity. 
A few scholars have called attention to the need to reconsider and rework studies on masculinities and men in the light of colonialism and slavery, but such awareness is yet to gain firm foothold in the field (e.g., see Connell 2014, 2016; Morrell 1998, 2001a; Ratele 2020). Slavery and colonialism were ruthless, world re-configuring forces. Their effects linger in the former colonies but can also be traced in the history of the global ascendancy of the West.

Coloniality is a concept that is used to think through these effects and histories. Whereas colonialism signals to economic, political and administrative structures that for the most part were dismantled during the $20^{\text {th }}$ century, coloniality summons racist difference into the modern period (imbricating the colonial and modern), including the very ideas of life and being human, of economic orders, cultural imaginaries, and political assemblages. Coloniality refers to patterns of power, knowledge, being and meaning arising from the "racial" social classification of the world population under Eurocentered world power' (Quijano 2007a, 171). The concept surfaces the entanglement of heterarchies of 'domination and exploitation where the racial/ethnic hierarchy of the European/non-European divide transversally reconfigures all of the other global power structures, ... where racism becomes the organizing principle that structures all of the multiple hierarchies of the world-system' (Grosfoguel 2011, 11).

Whereas in some parts of the world the effects, patterns and heterarchies of coloniality on men and masculinities might be more readily visible, in others, the former slave-trading or colonizing nations, surfacing the traces and impact of colonial/modern racist power demands a decolonial attitude and exertions in order to decolonize studies of men and masculinity (in the latter regard, see Connell 2016). By a decolonial attitude is meant a position whose aim is to counter coloniality by seeking to subvert and interrupt the globally controlling logics of colonial/modern racist difference. Within masculinity studies to cultivate a decolonial attitude would entail reckoning with the persisting effects of colonialism in the global and local gender orders and relations. To adopt an attitude of decoloniality is to strive to bring to light the problems of working on masculinity in the wake of colonialism, to not minimize colonialism and its legacies as if these are footnotes in the formation of the colonial/modern world. Consider here how studies of men and masculinity have shown that masculinities are plural and fluid (Connell 2005; Hearn 2010). As Hearn and Kimmel $(2006,56)$ noted, 'the concept of masculinities in the plural has been extremely important ... in widening the analysis of men and masculinities within the gender order'. The significance of the notion of plurality notwithstanding, what coloniality enables is a consciousness of the foundational difference in the categories of men and masculinity; an awareness that exposes the possibility that the object of which 
we are speaking (men or masculinity) may not necessarily nor always be the same for colonist and colonized (see Lugones 2010).

It is common cause that colonized and enslaved men were not regarded as full men; implying not quite men in the way the ruling men were regarded as men. At best these not-quite-men were without the same rights as the colonizing masters. At worst, they were property of the masters. In this regard, Césaire (1972) said the colonized man is a thingified subject, indicating that he has been dehumanized, turned into an object. But let us not minimise what James said about Toussaint being 'a whole man' (1938/ $1989,290)$, suggesting that not all colonised and slave males were diminished by colonialism and slavery. Then Fanon $(1967 / 1952,1)$ came along and said 'the black is not a man', implying one can be an adult (human) male yet not be a man. It seems that we are faced with not only an ontological but also an epistemological and methodological conundrum in studies of men and masculinity, one produced by colonialism and slavery. It should also be borne in mind that whereas colonised countries overcame political colonialism, coloniality persists in the world (see Ndlovu-Gatsheni 2018), suggesting that the confounding problem of the coloniality of masculinity persists. As a result, against such a history and contemporary colonial/modern conditions whose effect was, among others, the dehumanization of some men, a troubling set of question arises for researchers in the field of men and masculinity. Seeing masculinity is 'simultaneously a place in gender relations, the practices through which men and women engage that place in gender, and the effects of these practices in bodily experience, personality and culture' (Connell 2005, 71), what is the place accorded to males once considered property in men and masculinities studies, how are the practices of these 'former properties' fathomable as men's, and what sorts of masculinities possibly emanate from the place these 'not-quite-men' occupy?

\section{What this contribution seeks to do: call to resist coloniality and nurture decolonial attitudes}

In previous work that foregrounded coloniality (Ratele 2020), I introduced the concepts (non)men and (non)masculinity as conceptual resources in efforts to open up critical studies on men and masculinities to decolonial, southern and majority world-oriented perspectives (see Connell 2014, 526, on 'reconstructing the sociology of gender from Southern perspectives'). As so evocatively captured by Fanon's assertion above, non(men) are adult males who are not quite men, men who are confronted by the denial of their manhood by colonial Euroamerican-centred power. Having been enslaved and turned into property, non(men) contend with the misrecognition of their humanity at the same time as they face the denial of their 
manhood. Having been colonised they have to deal with being reduced to lesser men while struggling for recognition of their basic human rights. In other words, the struggles for being and for manhood are interwoven. The struggle for recognition as human and as men is one that their descendants have endured too (see Howard 1857 below). To speak of (non)men is thus to decolonially consider adult males who may look like men, yet, in the light of coloniality, given the denial of their masculinity (Suttner 2007), are not full men in the eyes of the colonizer (and sometimes their own eyes). To speak of (non)masculinity is to point to the unfathomable colonial gender position of these not-quite-men (Ratele 2020).

Within the colonial context the oppressor masculinity is the dominant form of masculinity (even if could be argued that it is not necessarily the hegemonic form, where consent is taken to be integral to hegemony, see Howson and Hearn 2020). Contrastingly, the masculinity of the colonised is, from the perspective of colonial gender power, 'outside' - subjugated, infantilized, criminalized or pathologized. There is internal diversity, of course. There is resistance, in different forms, against the colonizing masculinity among the colonized, of course. And there is opposition, insurgency and subordination within the colonizing group. But there is an irrefutable and constitutive colonial divide between men in the colony. And although further complexity gets introduced by the neo-colonial/postcolonial structures and mobilities, the effects of the oppressive divide can persist long after the formal dismantling of the colonial administration.

In arriving at the concepts (non)men and (non)masculinity I have drawn from and build upon the thinking of several masculinities scholars such as Robert Morell (2001a), Sakhumzi Mfecane (2018), and Raewyn Connell (2014), but also from a larger history made up of anti-colonial, postcolonial, decolonial, critical, and black thinkers from around the world (e.g., Biko 1978; Césaire 1972; Coates 2015; Ellison 2016; Fanon 1967/1952; hooks 2004; Lugones 2007; Mama 1997; Oyěwùmí 1997). Taking up Connell's idea of masculinity as place, the pair of concepts enable me to ask, what is the place of men who were not regarded as men and how might we think of their negated masculinity in critical studies of men and masculinities. Assuming that we are better if we cultivate a place for these figures once treated as property in critical men and masculinities studies, how are the practices of these 'former properties' intelligible as men's, and what masculinities emanate from the place/s these once 'non-beings' occupy? Whist this article might be seen as overly polemical and setting up binaries between the former colonies and metropole, it is hoped that its candor is interpreted as a challenge to us in the field to resist coloniality and an attempt to nurture a decolonial attitude in the field, particularly but not only work of men, boys, and masculinities in Africa. 
The article is also intended as an invitation for less ontological, epistemological and theoretical extraversion from those working in the ex-colonies (Hountondji 1987) in studies on men and masculinities. Following Hountondji, I see epistemological and theoretical extraversion as a practice within the global circulation of knowledge where what counts is what comes from the West and that tends to be slavishly followed by researchers from the Rest of the World, including former colonies in Africa (Hountondji 1990, 1995). Defined thus, extraversion is a consequence of internalized colonial domination materializing as an element of epistemic coloniality. However, coloniality is absolutely not restricted to the former colonies. It manifests itself in different practices and structures in the metropole too. Therefore, I extend an invitation for the cultivation of a decolonial attitude in all of us in critical men and masculinity work, whether this is undertaken in universities, research centers, cultural or religious communities, policy circles, sociopolitical activism, or psychoeducational programmes. Above all, I invite more of us to challenge coloniality and nurture decolonial attitudes epistemologies, conceptual tools, questions, tools, interpretations in studies on men and masculinities.

\section{A place for (non)men in the field of men and masculinities}

I now wish to turn to the possible a place/s of (non)men and (non)masculinity in the field on men and masculinities. Reflecting on coloniality is what enables us to (un)think colonised men as (non)men and (non)masculinity as the colonial gender position of these (non)men. Taking coloniality as 'the cornerstone of a Euro(american)centered world' (Quijano 2007b, 45), whilst acknowledging the possibility of resistance among the colonized and rebellion among the colonizers, I propose a differentiation between (a), colonialist work on boys, men and masculinity - by which is indicated colonizing Euroamerican-centring work, especially that work that is done in the excolonies and work intended to universalize Euroamerican colonial/modern normativity to the whole world - and (b), decolonial work on men and masculinities. It is in those instances when colonial studies on men and masculinities are undertaken by those who were themselves colonised that I refer to such work, after Hountondji above, as ontologically, epistemologically, theoretically extraverted. As Mfecane observes, 'contemporary masculinity theories are characterised by [the] "erasure" of the experience of the majority of men from their foundation. Founded in the West, masculinity theories generally reflect the experiences and "concerns" of their societies' (2016, 206).

The question of a place for (non)men arises precisely from fact that slavocratic and colonial racist logics construct some males as merchandise, 
inferior, without rights, meaning not human and not men. Consider here, as an example, the instructive case of Dred Scott versus John F. Sandford in the United States of America in which a former slave asked the courts to decide on his status. This is what Chief Justice Taney said,

They [slaves and their descendants] had for more than a century before been regarded as beings of an inferior order, and altogether unfit to associate with the white race, either in social or political relations; and so far inferior, that they had no rights which the white man was bound to respect; and that the negro might justly and lawfully be reduced to slavery for his benefit. He was bought and sold, and treated as an ordinary article of merchandise in traffic, whenever profit could be moved by it. This opinion was at that time fixed and universal in the civilized portion of the white race (Howard 1857, 407).

The slave and his descendant are property. They have no rights before the white man. Hence, they are not men in the way white men are men, with rights in a world in which rights are what gives recognition to the fundamental freedoms of humans to life, dignity and equality. But the question of a place for (non)men also goes to knowledge about them, to how they are written about and who writes about them.

When asking of the possible a place/s of (non)men and (non)masculinity in the field on men and masculinities, I am interested also in the legal and moral place of these subjects/objects in a legal and moral world in which they are not regarded as human, but I wish to confine myself here to an epistemological location and ontological space. As Fanon said, 'the black man has no ontological resistance in the eyes of the white man. Overnight the Negro has been given two frames of reference within which he has had to place himself' $(1967 / 1952,83)$. The idea of lack of ontological resistance reinforces the fact that colonised (non)man is merchandise and his/its being/nonbeing is constituted by Otherness. What Fanon means is that the colonised black man has no place, no rights, in a white man's world. Comprehending the nonbeing/ being of the colonised in the face of persisting white supremacy is intense affective and political work, implying it extends beyond cognitive labour. For the masculinity researcher, activist, policymaker or educator interested in understanding how these males become men in the light of the impossibility of being successfully masculine while Other in the dominant colonial frame of reference, the task is to work with them and interpret their lives and acts without referencing the colonial master frame.

(Non)men are what might be called the constitutive outside of masculinity studies: what is left outside the field yet what makes its existence possible (Mouffe 1991). Here we might also think of this category of males as exhibiting that pattern of masculinity found in the Western gender order that is referred to as marginalised masculinity by Connell (2005). However, the place of these males seems to lie beyond the margins. Absent yet present in the 
hierarchy of (Western) men, (non)men are, to borrow from Gordon (2007, 121) figures who 'have been located outside and thus, literally, without a place on which to stand' within men and masculinity studies. Colonialism was, in other words, the violent world-making force that denied some men masculinity (Suttner 2007). As a consequence of the colonial force and its lingering effects, there appears to be (a) no-place for these figures in studies of men and masculinity. To write about them is always an attempt to bring them into some kind of gendered existence, to find an epistemic place for them. What always needs ever closer examination is the sort of existence they thought to inhabit, the affects they are allowed to have, or the gender relations they can have without reference to colonial normativity. The implication is that those who desire decolonised studies of men and masculinity are called to create a better-defined place for these males in their work and design better tools to study gender life under coloniality. That place is a historicized cultural and structural situatedness.

A decolonial attitude requires reflecting on how coloniality shapes how men, in particular men who were once regarded as not quite human, continue to experience dehumanization or infrahumanization. The fact is that the dehumanized pasts of some men and the enduring associations of that history in the present congeals our understanding of them. To be exact, colonialism denied some males and females membership of the human. Coloniality has meant that this denial has persisted. Being not quite human, these males and females were not actually men and women but something that resembles men/women in form. The continuing struggle for many males in the post-colonies is ontological, in other words, a struggle for recognition for being human. The ontological struggle for recognition precedes and frames the struggle for masculinity. At least, the struggle to be seen as a man is imbricated with the struggle to be admitted as fully human. It is my sense that this struggle is not necessarily a conscious struggle. But it is felt in the pervasive sense of insecurity in the face of the ideology of white racist supremacy. It is experienced as a sense of precarious existence connected to the racialised colonial/capitalist economic order. It is substantiated by the anti-immigrant politics and the apparent lack of human empathy for African men, women and children, as well as other people of colour, who are left to die while trying to cross into Europe.

\section{How to think (of) africa (and african men) in studies on men and masculinities}

It is trite to say that Africa and the New World are places made of ex-colonies. Regarding Africa, which can be taken as one terrain in a history of colonialism, there is a relatively small but slowly growing body of work on men 
and masculinities. While working on this article, I conducted a search on Google Scholar to see the number of results 'African masculinity' and 'African masculinities' (using the exact phrases) returned. The search for 'African masculinity' (using the exact phrase) returned just over 1000 results and for 'African masculinities' slightly more than that. In comparison, the search for masculinity returned over 900000 hits and masculinities returned just over 200000 results. Admittedly, this is a crude and problematic measure. For one thing, the search for European masculinities/masculinities returns less than a thousand hits. The search for American masculinity/masculinities gets over 2000 hits. A problem with this measure is that publications could write on Africans and Africa without mentioning the two terms, choosing instead to mention a particular country, district, municipality, city, town or village. Africans can and do write about American or European masculinity/masculinities, and Europeans/Americans do write about Africans. The West dominates the global economy of knowledge and there is quite a bit of publications on men or masculinity in Africa from Europe- and US-based authors. Despite its crudeness, a Google Scholar search does give the beginnings of an excavation for writing on African masculinities. But beyond a beginning the measure offers an inadequate sketch as to the angles from which Africa is seen, how the men in that continent are seen, about the location who is writing on the topic, regarding interpretations or approaches, and as to what contributions are highly cited. With regard to citations, although there are contributions by authors based in other parts of the world, in it necessary to observe that the majority of the most highly cited journal articles on men and masculinities in Africa come from South Africa (e.g., Hunter 2005; Morrell 1998; Ratele 2008). I note the contributions and citations because to understand where they emerge from is to realise another instantiation of contemporary global apartheid patterning of knowledge production and circulation. It is also worth pointing out that publishing this article in the Gender, Place and Culture could be regarded as ironic. Yet the point being made here is precisely that epistemic coloniality has made it difficult for researchers in Africa and the broader global South to refuse publishing in journals published in the global North if they want recognition, not just internationally but, even more worryingly, in their home countries. Publishing in 'international' journals - meaning journal published in Western Europe and North America - is regarded by many African universities (but also other universities around the world) as more prestigious than publishing in journals published in African countries (see Hountondji 1995).

The racially differentiated, ex-colonizer/ex-colonised or centre/peripheries world economy of knowledge has other effects, some grand and others apparently petty. Exceptions no doubt exists. However, one effect of colonial/modern racist relations between the centre and peripheries in the global 
economy of knowledge is to encourage those of us located in the West - or the centre in the Rest of the World - to understate the power and privileges that accrue to us as a result of our situatedness within colonial modernity. Many of us are more likely to attribute much of our achievements to our natural individual effort and genius, and the development of our countries to the intelligence of our democratic leaders and efficiency of our systems. Another effect, apparently minor, is to reduce the demand on those located in the centre to clearly state the place from which we project when writing on men and masculinities (e.g., Allan 2018; Lombard 2013; Messner 2004; O'Brien, Hunt and Hart 2005). The reduced demand of researchers from the non-peripheries to locate themselves can reproduce coloniality. Conversely, there seems more of a compulsion, resulting in an invisible epistemic handicap, on those who write from or about the peripheries; a reflex for the local, a form of internalized duress to indicate the place from or about which we are writing. Sometimes the compulsion extends to indicate the village, town, city, province or country in the title of one's writing (e.g., Dery and Ganle 2020; Groes-Green 2012; Hollander 2014; Jaji 2009). Writing (about) Africa with the consciousness of coloniality is never untroubled (see Mbembe 2002). What troubles writing (about) Africa springs from epistemic coloniality and forms of epistemic injustice that flow from the former. In the aftermath of slavery and colonialism, writing (about) Africa has forever been complicated primarily because the terrain became tainted with racist stereotypes (which are often enough internalized by the former colonised), exoticizing claims, flattening generalizations, mythologizing tropes. As such, African writers writing on African men and masculinities cannot write what they like, as Premesh Lalu (2004) remarked on Biko's famous text, I write what I like. In writing Africa, African scholars, activists and educators are often forced to localize their knowledge claims or minimize the experience about which they speak. Researchers are often pressured, or may feel that they are pressured, to specify the site where they conducted their studies and limit their claims only to that site. To a substantial degree Africa therefore still tends to be a homogenized, spectral figure in the global social science, health and the humanities mainstream dominated by the global North. More crucially, within studies on men and masculinities in Africa, the continent tends not to be thought of as a site of theory-generation for the world, if not for itself. On the back of this claim, below I briefly introduce a simplified distinction in the way work on masculinities in the wake of colonialism might be thought of, conducted and read.

\section{Two approaches to coloniality in work on men and masculinities}

At the risk of over-simplifying, there are at least two attitudes to coloniality in work on boys, men and masculinities. A key distinguishing feature of 
these perspectives is how the fact of the coloniality is apprehended, whether it is minimized, disregarded or reproduced as opposed to whether it is given its due weight, critiqued, or challenged.

On the one hand we have what should be referred to as ontologically, epistemologically or theoretically extraverted projects (Hountondji 1987, 1990, 1995). The preponderance but not all projects on men and masculinities in former colonies and those projects that seek to universalize the object men/masculinities fall in here. These are projects that tend to be saturated with coloniality. Even while they may be conducted in African countries, these tend to centre Western colonial ontologies, epistemologies, theories, questions, and audiences.

On the other hand, there is a small body of work whose objectives are to challenge and disrupt colonialist Euroamerican-centrism and its effects (e.g., see Connell 2014, 2016; Mfecane 2016, 2018; Morrell 1998, 2001a; Ratele 2017, 2020). The work comes under different labels such as Southern perspectives (Connell 2014), indigenous knowledge, and African-centred theories (Mfecane 2018). Regardless, what distinguishes the work is that it foregrounds colonialism and its aftermath. Connell (2016), for example, has discussed a decolonizing approach as a route to grasp 'masculinity and hegemony on a world scale today' (304). Mfecane (2018) has examined 'the concept of indoda as an example of an African-centred theory of masculinity' (206).

\section{Work on men and masculinities that reproduces coloniality}

Within ontologically, epistemologically or theoretically extraverted projects on men and masculinities, meaning work that materializes coloniality, the excolonies in Africa (but also other ex-colonies in Asia and Latin America) are usually primarily used as sites of data collection (Hountondji 1987, 1990, 1995). Sometimes these sites appear as application sites. But the main trouble is that they rarely are assumed as places of theory-making or conceptproduction. The most obvious example of places in Africa sites of data extraction or application are intervention studies aimed at engaging or involving men and boys towards gender equality and transforming masculinities (Mills et al. 2012; Slegh et al. 2013; Stern et al. 2015). Such work can contribute towards studies on masculinities global studies on masculinities, certainly (Inhorn 2003; Kagaba 2015; Trenholm et al. 2013; Rich, Nkosi, and Morojele 2015). But these are contributions that appear to be unaware of coloniality, or otherwise neglect to highlight it. Hence, there are troublesome issues that ought to be raised. For instance, in respect of studies that aim to transform boys and men, it should be asked (taking work on men and boys in Africa as a case in point), to what end are African boys and men being changed, given the history of slavery, colonialism, and apartheid? Are African 
men being transformed to be equal with African women only, or are they being transformed to be equal with all women? In other words, does gender transformative work with African men take into account global colonial/modern world order, racial inequality, and geopolitical South/North inequalities into consideration? Are the men and boys in the former colonies being transformed into the equals of the men and boys in the ex-colonizing nations or not?

Work on men and masculinities that tends to reproduce coloniality may not deliberately seek to colonize or reproduce colonial difference between men. However, it can perpetuate coloniality by effectively ignoring, dismissing, concealing, or minimizing its effects because it understands a place and life in a place in Africa from elsewhere. That elsewhere is usually the global North, which tends to be informed by a theoretical, epistemological or ontological standpoint of colonial extraversion (Hountondji 1990, 1995). We can then also refer to this type of work as Euroamerican-centring labour - conceding that, within the broad umbrella, there are differences.

Work on masculinity saturated by or blind to coloniality is and can be done anywhere in the world. Yet it is always angled towards the demands of readers, funders, journals or book publishers located in Western Europe and North America. Such work usually does not endeavour to decolonise persisting unequal epistemic, gender, and cultural relations. As such, there is a profound question for those of us - activists, educators, community actors, students, funders, researchers or policymakers - working on altering masculinities and gender relations: what precisely are Euroamerican-centring projects on boys, men, masculinities, in particular Euroamerican-centring work undertaken in Africa, contributing towards transforming global and local relations among men, and between men and other genders, when they do not also intend to decolonise these relations?

\section{Toward decolonial work on men and masculinities}

In the knowledge economies evident in African countries a total avoidance and resistance of the hegemony of Western languages, categories of thought, theories, concepts, views and approaches is currently difficult, and African researchers, university teachers and activists in working in the area of boys, men and masculinities are usually no better than actors in other areas in evading Euroamerican hegemony. Despite the global domination of the West over the Rest, though, possibilities to decolonise work on boys, men and masculinities exist. One position from which to begin such work is in taking the ex-colonies as active, creative and meaningful spaces in which many, rich, contesting, and dynamic accounts of gender and masculinities exists. Several authors have made critical contributions to men and masculinity studies in this respect (e.g., Mfecane 2016, 2018; Morrell 2001a, 2001b; 
Mugambi and Allan 2010; Nyanzi, Nyanzi-Wakholi, and Kalina 2009; Ouzgane and Morrell 2005; Ratele 2011, 2014, 2017; Reid and Walker 2005; Uchendu 2008). However, in some of these otherwise critical contributions, a dominant space is sometimes given to Western ethnocentric thought. In contrast, a decolonial attitude urges us to begin from the position that the ex-colony is not only a place of meaning-making but also offering explanations of masculinities from where the subjects exist. In this latter position is to be found work whose objectives is to explicitly challenge Euroamerican-centrism and colonialism (e.g., see Connell 2016; Mfecane 2018; Morrell 1998; Ratele 2017).

Decolonial work seeks to ontologically, epistemologically and theoretically centre coloniality in thinking through the worlds of (non)men and their place in global and local gender relations. Instead of an over-dependency on Western ethnocentric ontologies, epistemologies, and theories, such work conceives of (non)men and their non(masculinity) from their situatedness in that place. A decolonial approach is what enables us to decolonise work on men and masculinities studies in former colonies but also work that intends to universalize colonialist Euroamerican-centricity. A profound necessity, from an African-centred decolonial perspective, is to treat African countries not as merely sites of extractive data gathering but also as offering explanations. Work informed by a decolonial attitude does not stop at theorising the lives of (non)men, in seeing these lives in their fullness and meaningfulness against a history of racist and ethnocentric stereotypes and marginalization, but at the same time to give recognition of the humanity of these men. African-centred decolonial projects invite an epistemic struggle to understand men and masculinities in context, to reject the dominance of colonialist research methods, theoretical models, analyses, and interventions. Because they foreground coloniality, decolonial African-centred approaches makes it possible to see (non)men and to make a place/places for them in masculinities studies.

\section{Conclusion}

Instead of repeating what I have tried to say in the article, I would like to highlight the invitation for a decolonial attitude in the global work of men and masculinities as an attempt to, first, make a place for what I refer to as (non)men, and second, meaningfully situate places in the ex-colonies as theory-making sites. The article discussed how colonized and enslaved men were regarded as property, or having lesser rights, if any, compared to the enslavers and colonizers, and therefore not quite men. I noted what Fanon said about some men as not men and what Cesaire said about some men as things. But I also called attention to James' observation about Toussaint, and slave, being a full man, offering us the possibility of resistance. I asked what an adult male is, if not a man. I suggested that studies of men and 
masculinity are faced with ontological, epistemological and methodological puzzle. It is in the light of this that the article makes a call for decolonial attitudes, approaches, concepts, tools, explanations, politics, and creative work in studies on men masculinities. As I speak from a particular place in the world, and exBritish colony in Africa, I especially invite those who write from Africa (and other ex-colonies) about boys, men and masculinities to nurture decolonial approaches to masculinity studies and not succumb to the pressures to subscribe to dominant Western-centric and colonial ideas about gender, boys, and men. The call and invitation are not, to be clear, for essentialisation. To the contrary, this call and invitation is for better situated, non-exoticizing and pluralistic ways of seeing and working with all men and boys, and in particular of conceiving, speaking, or writing (about) African men as an ordinary part of the world of men, and so for decolonial studies that consider African men qua Africa. Such studies, that look at African men and masculinities qua Africa, have tended to be relatively marginal (but not absent) in the global corpus of international studies on men and masculinities.

A decolonial attitude calls for a radical consciousness of the history of the world-reconfiguring force of colonialism and slavery. It implies deliberately moving against coloniality, not just at the levels of theoretical explanations, but also the levels of ontology, episteme, concepts, language, method and questions. A decolonial attitude enables research, courses, sociopolitical projects, policy-work and interventions that are less readily yielding to the dominance of Euromerican-centrist colonial lenses on and with boys, men and masculinities. Such work refuses to minimize the experience about which they write and to render their own explanations as exotic or homogenous. It challenges the pressure to limit its claims only to the site of data collection. It takes a decolonial turn as it centers, in the case of Africa, Africa primarily (but not only) for Africa. To think decolonially, taking cognizance of situatedness of men's practices and relations in the ex-colony, is therefore to trouble the idea of men (and women) as naturally belonging to one category, to refuse the taken-for-granted in thinking and engaging the colonizing man and colonised (non)man. Hence, the dilemma for decolonial work is precisely to be aware of the colonial difference yet seek to undo it.

\section{Acknowledgements}

I wish to thank the two anonymous reviewers of this article. Grateful acknowledgement also to Carole Ammann and Sandra Staudacher for their steadfastness and leading us on the special issue on masculinities in Africa.

\section{Disclosure statement}

No potential conflict of interest was reported by the author(s). 


\section{Funding}

This work was supported by the South African Medical Research Council/University of South Africa's Masculinity and Health Research Unit; and the University of South Africa's Institute for Social and Health Sciences.

\section{Notes on contributor}

Kopano Ratele is the Director of the South African Medical Research Council Masculinity \& Health Research Unit and Professor at the University of South Africa where he runs the Transdisciplinary African Psychologies Programme. He has published extensively and his books include There Was This Goat: Investigating the Truth Commission Testimony of Notrose Nobomvu Konile (2009, co-authored with Antjie Krog and Nosisi Mpolweni), Liberating Masculinities (2016), Engaging Youth in Activism, Research and Pedagogical Praxis: Transnational and Intersectional Perspectives on Gender, Sex, and Race (2018, coedited with Jeff Hearn, Tammy Shefer, and Floretta Boonzaier) and The World Looks Like This From Here: Thoughts on African Psychology (2019).

\section{ORCID}

Kopano Ratele (D) http://orcid.org/0000-0002-1688-5136

\section{References}

Allan, Jonathan A. 2018. "Masculinity as Cruel Optimism." Norma 13 (3-4): 175-190. doi: 10.1080/18902138.2017.1312949.

Biko, Steve. 1978. I Write What I like: A Selection of His Writings. Randburg: Ravan Press.

Césaire, Aime. 1972. Discourse on Colonialism. New York: Monthly Review Press

Coates, Ta-Nehisi. 2015. Between the World and Me. New York: Spiegel \& Grau.

Connell, Raewyn W. 2005. Masculinities. Berkeley: University of California Press.

Connell, Raewyn W. 2014. "The Sociology of Gender in Southern Perspective." Current Sociology Monograph 62 (4): 550-567. doi:10.1177/0011392114524510.

Connell, Raewyn W. 2016. "Masculinities in Global Perspective: Hegemony, Contestation, and Changing Structures of Power." Theory and Society 45 (4): 303-318. doi:10.1007/ s11186-016-9275-x.

Dery, Isaac, and John K. Ganle. 2020. "Who Knows, You May Overpower Him': Narratives and Experiences of Masculinities among the Dagaaba Youth of Northwestern Ghana." The Journal of Men's Studies 28 (1): 82-100. doi:10.1177/1060826519846932.

Ellison, Ralph. 2016/1952) Invisible Man. London: Penguin.

Fanon, Frantz. 1967/1952. Black Skins, White Masks. New York: Grove Press.

Gordon, Lewis R. 2007. "Problematic People and Epistemic Decolonization: Toward the Postcolonial in Africana Political Thought." In Postcolonialism and Political Theory, edited by N. Persram, 121-142. Landham, MD: Lexington Books.

Groes-Green, Christian. 2012. "Philogynous Masculinities: Contextualizing Alternative Manhood in Mozambique." Men and Masculinities 15 (2): 91-111. doi:10.1177/1097184X11427021.

Grosfoguel, Ramon. 2011. "Decolonizing Post-Colonial Studies and Paradigms of PoliticalEconomy: Transmodernity, Decolonial Thinking, and Global Coloniality." Transmodernity: Journal of Peripheral Cultural Production of the Luso-Hispanic World 1 (1). https://escholarship.org/uc/item/21k6t3fq. 
Hearn, Jeff. 2010. "Reflecting on Men and Social Policy: Contemporary Critical Debates and Implications for Social Policy." Critical Social Policy 30 (2): 165-188. doi:10.1177/ 0261018309358288.

Hearn, Jeff, and Kimmel Michael. 2006. "Changing Studies on Men and Masculinities." In Handbook of Gender and Women's Studies, edited by Kathy Davis, Mary Evans, and Judith Lorber, 53-70. London: SAGE.

Hollander, Theo. 2014. "Men, Masculinities, and the Demise of a State: Examining Masculinities in the Context of Economic, Political, and Social Crisis in a Small Town in the Democratic Republic of the Congo." Men and Masculinities 17 (4): 417-439. doi:10. 1177/1097184X14544906.

hooks, bell. 2004. We Real Cool: Black Men and Masculinity. New York: Routledge.

Hountondji, Paulin J. 1987. "On the Universality of Science and Technology." In Deutschen Soziologentages in Hamburg 1986: Technik Und Sozialer Wandel: Verhandlungen Des 23, edited by Burkart Lutz, 382-389. Frankfurt am Main: Campus Verl. http://nbn-resolving. de/urn:nbn:de:0168-ssoar-149164.

Hountondji, Paulin J. 1990. "Scientific Dependence in Africa Today." Research in African Literatures 21 (3): 5-15.

Hountondji, Paulin J. 1995. "Producing Knowledge in Africa Today: The Second Bashorun M. K. O. Abiola Distinguished Lecture." African Studies Review 38 (3): 1-10. doi:10.2307/ 524790.

Howard, Benjamin C. 1857. A Report of the Decision of the Supreme Court of the United States and the Opinions of the Judges Thereof in the Case of Dred Scott versus John F. Sandford, December Term 1856. New York. D. Appleton \& Co.

Howson, Richard, and Jeff Hearn. 2020. "Hegemony, Hegemonic Masculinity, and beyond." In Routledge International Handbook of Masculinity Studies, edited by Lucas Gottzén, Ulf Mellström, and Tamara Shefer, 41-51. London: Routledge.

Hunter, Mark. 2005. "Cultural Politics and Masculinities: multiple-partners in historical perspective in KwaZulu-Natal ." Culture, Health \& Sexuality 7 (3): 209-223. doi:10.1080/ 13691050412331293458.

Inhorn, Marcia C. 2003. "The Worms Are Weak': Male Infertility and Patriarchal Paradoxes in Egypt." Men and Masculinities 5 (3): 236-256. doi:10.1177/1097184X02238525.

Jaji, Rosemary. 2009. "Masculinity on Unstable Ground: Young Refugee Men in Nairobi, Kenya." Journal of Refugee Studies 22 (2): 177-194. doi:10.1093/jrs/fep007.

James. Cyril L. R. 1938/1989. The Black Jacobins: Toussaint L'Ouverture and the San Domingo Revolution. New York: Vintage.

Kagaba, Mediatrice. 2015. “Threatened Masculinities: Men's Experiences of Gender Equality in Rural Rwanda." Masculinities: A Journal of Identity and Culture 3: 55-85.

Lalu, Premesh. 2004. "Incomplete Histories: Steve Biko, the Politics of Self-Writing and the Apparatus of Reading." Current Writing 16 (1): 107-126. doi:10.1080/1013929X.2004. 9678187.

Lombard, Kara-Jane. 2013. "Men against the Wall: Graffiti(ed) Masculinities." The Journal of Men's Studies 21 (2): 178-190. doi:10.3149/jms.2102.178.

Lugones, Maria. 2007. "Heterosexism and the Colonial/Modern Gender System." Hypatia 22 (1): 186-219. doi:10.1353/hyp.2006.0067.

Lugones, Maria. 2010. “Toward a Decolonial Feminism." Hypatia 25 (4): 742-759. doi:10. 1111/j.1527-2001.2010.01137.x.

Mama, Amina. 1997. "Sheroes and Villains: Conceptualizing Colonial and Contemporary Violence against Women in Africa." In: Feminist Genealogies, Colonial Legacies, 
Democratic Futures, edited by Jacqui Alexander and Chandra Mohanty, 46-62. New York: Routledge.

Mbembe, Achille J. 2002. "African Modes of Self-Writing." Public Culture 14 (1): 239-273. doi:10.1215/08992363-14-1-239.

Messner, Michael A. 2004. "On Patriarchs and Losers: Rethinking Men's Interests." Berkeley Journal of Sociology 48: 74-88.

Mfecane, Sakhumzi. 2016. "Ndiyindoda' [l Am a Man]: Theorising Xhosa Masculinity." Anthropology Southern Africa 39 (3): 204-214. doi:10.1080/23323256.2016.1208535.

Mfecane, Sakhumzi. 2018. "Towards African-Centred Theories of Masculinity." Social Dynamics 44 (2): 291-305. doi:10.1080/02533952.2018.1481683.

Mills, Edward J., Chris Beyrer, Josephine Birungi, and Mark R. Dybul. 2012. "Engaging Men in Prevention and Care for HIV/AIDS in Africa." PLoS Medicine 9 (2): e1001167. doi:10. 1371/journal.pmed.1001167.

Morrell, Robert. 1998. "Of Boys and Men: masculinity and Gender in Southern African Studies." Journal of Southern African Studies 24 (4): 605-630. doi:10.1080/ 03057079808708593.

Morrell, Robert. 2001a. From Boys to Gentlemen: Settler Masculinity in Colonial Natal, 1880-1920. Pretoria: University of South Africa.

Morrell, Robert, ed. 2001b. Changing Men in Southern Africa. Pietermaritzburg: University of Natal Press.

Mouffe, Chantal. 1991. "Democratic Citizenship and the Political Community." In Community at Loose Ends, edited by Miami Theory Collective, 70-82. Minneapolis: University of Minnesota Press.

Mugambi Helen Nabasuta and Allan Tuzyline Jita Allan. 2010. Masculinities in African Literary and Cultural Texts. Oxofrdshire: Banbury Ayebia Clarke Publishing Ltd.

Ndlovu-Gatsheni, Sabelo J. 2018. Epistemic Freedom in Africa: Deprovincialization and Decolonization. New York: Routledge.

Nyanzi, Stella, Barbara Nyanzi-Wakholi, and Bessie Kalina. 2009. "Male Promiscuity: The Negotiation of Masculinities by Motorbike Taxi-riders in Masaka, Uganda." Men and Masculinities 12 (1): 73-89.

O'Brien, Rosaleen, Kate Hunt, and Graham Hart. 2005. "It's Caveman Stuff, but That is to a Certain Extent How Guys Still Operate': men's Accounts of Masculinity and Help Seeking." Social Science \& Medicine (1982) 61 (3): 503-516. doi:10.1016/j.socscimed.2004.12.008.

Ouzgane, Lahoucine, and Robert Morrell, eds. 2005. African Masculinities: Men in Africa from the Late Nineteenth Century to the Present. New York: Palgrave Macmillan.

Oyeronke, Oyěwùmí. 1997. The Invention of Women: Making an African Sense of Western Gender Discourses. Minneapolis: University of Minnesota Press.

Quijano, Anibal. 2007a. "Coloniality and Modernity/Rationality." Cultural Studies 21 (2-3): 168-178. doi:10.1080/09502380601164353.

Quijano, Anibal. 2007b. "Questioning "Race." Socialism and Democracy 21 (1): 45-53. doi: 10.1080/08854300601116704.

Ratele, Kopano. 2008. "Analysing Males in Africa: Certain Useful Elements in considering Ruling Masculinities." African and Asian Studies 7 (4): 515-536. doi:10.1163/ $156921008 \times 359641$.

Ratele, Kopano. 2011. "Male Sexualities and Masculinities." In: African Sexualities: A Reade, edited by Sylvia Tamale, 399-419. Nairobi: Pambazuka Press.

Ratele, Kopano. 2014. "Currents against Gender Transformation of South African Men: Relocating Marginality to the Centre of Research and Theory of Masculinities." Norma 9 (1): 30-44. doi:10.1080/18902138.2014.892285. 
Ratele, Kopano. 2017. "African (Situated) Psychologies of Boys, Men and Masculinities." Psychology in Society (PINS) 54: 10-28. 10.17159/2309-8708/2017/n54a2.

Ratele, Kopano. 2020. "African and Black Men and Masculinities." In Routledge International Handbook of Masculinity Studies, edited by Lucas Gottzén, Ulf Mellström, and Tamara Shefer, 125-134. London: Routledge.

Reid, Graeme, and Liz Walker, eds. 2005. Men Behaving Differently. Wetton: Double Storey.

Rich, Eileen P., Sebenzile Nkosi, and Neo K. Morojele. 2015. "Masculinities, Alcohol Consumption, and Sexual Risk Behavior among Male Tavern Attendees: A Qualitative Study in North West Province, South Africa." Psychology of Men \& Masculinity 16 (4): 382-392. doi:10.1037/a0038871.

Slegh, Henny, Gary Barker, Augustin Kimonyo, Prudence Ndolimana, and Matt Bannerman. 2013. "I Can Do Women's Work': reflections on Engaging Men as Allies in Women's Economic Empowerment in Rwanda." Gender \& Development 21 (1): 15-30. doi:10.1080/ 13552074.2013.767495.

Stern, Erin, Laura Pascoe, Tim Shand, and Samantha Richmond. 2015. "Lessons Learned from Engaging Men in Sexual and Reproductive Health as Clients, Partners and Advocates of Change in the Hoima District of Uganda." Culture, Health \& Sexuality 17 (sup2): 190-205. doi:10.1080/13691058.2015.1027878.

Suttner, Raymond. 2007. "Masculinities in the ANC Led Liberation Movement." In: From Boys to Men. Social Construction of Masculinity in Contemporary South Africa, edited by Tamara Shefer, Kopano Ratele, Anna Strebel, Nokuthula Shabalala, and Rosemarie Buikema. 195-224. Landsdowne: UCT Press.

Trenholm, Jill, Pia Olsson, Martha Blomqvist, and Beth Maina Ahlberg. 2013. "Constructing Soldiers from Boys in Eastern Democratic Republic of Congo." Men and Masculinities 16 (2): 203-227. doi:10.1177/1097184X12470113.

Uchendu, Egodi, ed. 2008. Masculinities in Contemporary Africa. Dakar: Council for the Development of Social Science Research in Africa (CODESRIA). 